\title{
Colonial Virginia's paper money, I755-I774: value decomposition and performance
}

\author{
FARLEY GRUBB \\ University of Delaware
}

\begin{abstract}
Colonial Virginia's legislature introduced an inside paper money into its domestic economy that was, at that time, primarily a barter economy without any government or bank-issued inside paper monies in circulation. I decompose Virginia's paper money into its expected real-asset present value, risk discount and transaction premium. The value of Virginia's paper money was determined primarily by its real-asset present value. The transaction premium was small. Positive risk discounts occurred in years when monetary troubles were suspected, namely worries that the government would not redeem the paper money as promised. Counterfeiting, however, was not one of these worries. The legislature had the tools and used them effectively to mitigate the effects of counterfeiting on the value of its paper money. Colonial Virginia's paper money was not a fiat currency, but a barter asset, with just enough transaction premium to make it the preferred medium of exchange for local transactions. It functioned like a zerocoupon bond and traded below face value due to time-discounting, not depreciation.
\end{abstract}

Keywords: asset money, bills of credit, counterfeiting, transaction premium, zero-coupon bonds

JEL classification: $\mathrm{E}_{42}, \mathrm{E}_{5} \mathrm{I}, \mathrm{G}_{12}, \mathrm{H}_{60}, \mathrm{~N}_{12}, \mathrm{~N}_{22}$

How can an inside paper money be introduced into a financially underdeveloped barter economy? How can its value be maintained? Will it actually serve as money? Answers to these questions are explored using colonial Virginia's paper money. The British North American colonies were the first Western economies to emit sizable amounts of colony-specific paper monies that served as a circulating medium within each colony (Brock I975; Grubb 2016a).

Virginia had the second largest free population of the I 3 colonies (Carter et al. 2006, vol. 5, p. 652). In I755, Virginia became the last of these colonies to emit paper money. The performance of Virginia's paper money is central to the history of the period; it was at the center of the conflict with the British Crown over colonial

F. Grubb, Professor and NBER Research Associate, Economics Department, University of Delaware, Newark, DE 19716, USA. Email: grubbf@udel.edu. Website: www.lerner.udel.edu/faculty-staff/ faculty/farley-grubb. Preliminary versions were presented at Vanderbilt University, October 20 I5; NBER Cambridge, MA, July 20I6; Washington DC Area Economic History Seminar at American University, March 20I7; and the 8th World Congress of Cliometrics, Strasbourg, France, July 2017. The author thanks the participants and anonymous referees for helpful comments. Research assistance by Changqing $\mathrm{Mu}$ and editorial assistance by Tracy McQueen are gratefully acknowledged. 
monetary powers and provided Parliament justification for passing the Currency Act of I764 (4 Geo III c. 34). This conflict contributed to revolutionary sentiments. Virginia's paper money was a contentious point within Virginia politics due to irregular activities by Virginia's treasurer. Virginia's administrative structure was altered as a result, with the positions of Treasurer and Speaker of the House no longer allowed to be held by the same person (Brock I975, pp. 465-527; Ernst I973; Greene and Jellison I96I; Labaree I959-70, vol. 9, pp. I3 I-53; Mays I952, vol. I, pp. I74-208, 358-85).

Virginia's legislature had paper money printed and placed in its treasury. It spent this money directly out of the treasury into public circulation. This was the only paper money in circulation. No banks issuing paper banknotes existed in colonial America (Hammond I99I, pp. 3-67). Prior to emitting paper money, Virginia's medium of exchange consisted of barter, typically involving book credit transactions and tobacco - often in the form of claims to tobacco or tobacco notes; personal bills of exchange and promissory notes; and foreign specie coins (Breen I985, pp. 94-7; Tillson 20I0, pp. 36-8, 64). The composition of this medium is unknown, though specie coins were considered relatively scarce. Virginia referred to its paper money as treasury notes. Other colonies referred to their paper monies as bills of credit. While treasury notes were the same as bills of credit, I will refer to Virginia's paper money as notes in keeping with Virginia's terminology (Hening I969, vol. 7, p. 353).

The article proceeds as follows: Section I explicates the state of the modern debate over colonial paper money and why colonial Virginia provides a new and important contribution to our understanding of colonial paper money. Section II presents the institutional and public finance structure of Virginia's paper money emissions, including yearly net new emissions, redemptions and amounts in public circulation. Section III presents a decomposition model for inside monies and shows how the data are used to construct model components. Section IV presents the empirical application of the model and addresses historical episodes involving treasurer malfeasance and counterfeiting. Section v econometrically estimates the determinants of the model's components. Section VI concludes.

The modern analysis of colonial paper money has proven contentious. This is because theorists performed the analyses with the goal of championing favored monetary models using data found in the secondary literature - data gathered in the I93os and I940s. They had little interest in the actual financial history of individual colonies or in vetting and updating the data on colonial monetary accounts, prices and exchange rates. The assumptions needed to make their models yield the desired results were confused for observed facts, turning investigative exercises into hardened ideological positions that generated acrimonious debates.

It started with Roger Craig West (1978) testing a simple version of the quantity theory of money on colonial New York, Pennsylvania and South Carolina - the only colonies south of New England with price indices available in the secondary 
literature. For each colony, West found no relationship between that colony's paper money in circulation and that colony's price index. From here on, this finding became the core observed fact needing explanation. This failure of the quantity theory of money led to theoretical augmentations to that theory that could account for no relationship between paper money supplies and prices.

Theorists pursued two primary augmentations. The first used rational expectations and the laws requiring the removal of paper money to argue that citizens could undo the current price effects of current paper money increases. They could do this by adjusting their current behavior to the anticipated legally mandated future paper money decreases directly tied to the current paper money increases (Smith I985a, I985b, I988; Sumner I993; Wicker I985).

These studies do not sufficiently articulate the mechanism, or chart the behavioral dynamic, that led to no relationship between paper money supplies and prices. Within the quantity theory, the mechanism requires contemporaneous changes in the velocity of circulation perfectly to offset changes in paper money supplies thus leaving current prices unchanged, other things equal. Evidence for this behavior is scant, and the velocity changes needed to account for no relationship between paper money supplies and prices are too large to be credible (Cutsail and Grubb 20 I 7; Grubb forthcoming). The emphasis in this line of analysis is on the monetary theory and not on documenting the financial history of the colonies addressed. Oddly, the literature refers to this line of analysis as 'backing' theory.

The second theoretical augmentation used currency substitution theory to argue that changes in the supply of foreign specie coins via imports and exports of coins perfectly offset changes in local paper money supplies leaving the total money supply (assumed to be only paper and coins) constant and so prices unchanged. Currency substitution could produce no relationship between paper money supplies and prices, but only under particular conditions. These conditions are a functioning and defended fixed exchange rate, executed upon demand, between foreign specie coins and paper money, as well as between the separate paper monies of individual colonies, and a fully monetized economy. In addition, costless importing and exporting of foreign coins, no opportunity cost to using foreign coins for domestic transactions, and a sufficient reservoir of foreign coins in a colony perfectly to offset changes in paper money supplies are required (Grubb 2004; McCallum I992; Michener I987, I988, 20I5).

Direct evidence on these conditions is scant, and the preponderance of institutional structures, indirect evidence and rational behaviors speaks against the likelihood that these conditions are manifest in colonial economies (Cutsail and Grubb 20 I7; Grubb 2006, 2012, 20I6a). Again, the emphasis in this line of analysis is on the monetary theory and not on documenting the financial history of the colonies addressed. Oddly, the literature refers to this line of analysis as 'quantity' theory even though it is currency substitution theory under an assumed fixed exchange rate regime.

The contentious acrimony in this scholarship comes from theorists taking the assumed conditions (A) needed for their favored model to yield the observed result 
of no relationship between paper money supplies and prices $(B)$ and then conflating (A) with actual observed facts. Given the true proposition: if (A) is true, then (B) is true, these scholars slide into concluding: given that $(B)$ is true, then $(A)$ must be true. This conclusion is a classic error in logic because non-(A) conditions might also make (B) true. This error turns investigative empirical exercises into hardened ideological positions where (A) must be defended as observed fact at all costs to save the favored model even when there is little evidence that (A) is an observable fact (Grubb 2006, pp. 49-50). Again, the emphasis is on defending favored monetary theories and not on investigating the actual financial history of individual colonies. The history part of financial history is lost in the modern analysis of colonial paper money.

What follows breaks free from this narrow, stilted and stale modern debate and its emphasis on championing favored monetary models. Instead, I devise a new analytical and monetary modeling approach - one tailored to colonial economies and their institutional constraints and one that allows for an evaluation of the particular financial history of individual colonies. The emphasis here is on documenting various aspects of the actual financial history and public finance of the colony addressed as well as various financial behaviors exhibited by that colony's citizens when that colony emitted paper money. In addition, I use original sources to vet, update and expand the data on colonial monetary accounts, using much improved data over that gathered mostly in the I940s and used by previous studies in the modern literature.

Each colony had their own separate budget and ran their own fiscal and monetary policy. Colonies did not coordinate their policies to any significant degree. Colonies had considerable latitude over and exercised considerable variation in how they designed their paper money systems. Unintended, uncoordinated and differentiated experimentation on a grand scale was afoot from colony to colony regarding how to run a paper money regime. While some commonality in institutional structures, British oversight, and so modeling approaches exist, the financial history of each colony differed substantially (Grubb 20I6a). Comparing the results here for colonial Virginia with those for colonial New Jersey, Maryland and North Carolina shows the uniqueness of each colony's financial history regarding the performance of their paper money regimes (Celia and Grubb 2016; Cutsail and Grubb 2017; Grubb 2016b).

Colonial Virginia has not yet figured in any of the modern studies on colonial paper money. Thus, analyzing the financial history of colonial Virginia's paper money regime is a unique and new contribution in itself. In addition, several features of colonial Virginia's paper money regime, not easily studied in other colonies, can enlighten our general understanding of colonial monetary systems. These features include Virginia's restructuring of emission redemptions to yield commonality in maturity dates, Parliament's ban on legal tender paper money and the impact of the Seven Years' War. In addition, two features of Virginia's paper money regime were unique major monetary events, namely a malfeasance episode committed by the colony's treasurer and a significant counterfeiting episode. How colonial Virginia handled these episodes is informative of how other colonies could have handled such traumatic events. 
Budgetary crises caused by wars typically pushed colonies into paper money systems (Grubb 20I6a). Virginia did not face such a crisis until the Seven Years' War. The immediate and large spending demands of Virginia's participation in that war swamped Virginia's ability immediately to raise enough taxes to meet these expenses (Brock I975, pp. 466-9, 476).

Colonial governments faced standard budget constraints. Tax receipts had to match spending; when they did not, colonial governments had to adjust their borrowing and asset positions. Colonial governments did not have asset positions, such as stocks of gold and land. External markets where colonial governments could borrow were not adequately developed or accessible (Brock I975, pp. 467-9). Thus, when current tax receipts did not match current spending, colonial governments had to move tax receipts through time to balance budgets.

Virginia did this by issuing treasury notes as a paper money $(M)$, see equation (I). These notes were a credit-debt mechanism that matched budget deficits with budget surpluses over a multi-year horizon. Colonial paper money Acts included concurrent tax legislation designed to redeem the notes emitted at their face value in the near future. Redeemed notes were to be removed from circulation and destroyed.

$$
0<\left(G_{j}-T_{j}\right)=M_{j} \leq \sum_{\mathrm{t}=\mathrm{j}+1}^{N}\left(T m_{t}+T_{t}-G_{t}\right)>0
$$

$M_{\mathrm{j}}=$ new emissions of $M$ (treasury notes) in year $\mathrm{j}$

$T=$ spendable revenue taxes not specifically created to redeem $M$

$T m=$ taxes specifically created to redeem and remove $M$ from circulation

$G=$ government spending

To maintain fiscal credibility, future taxes in excess of spending, $\left(T m_{\mathrm{t}}+T_{\mathrm{t}}-G_{\mathrm{t}}\right)>$ o, had to be spread over numerous years, especially when $M_{\mathrm{j}}$ was large. This process allowed a colony to marshal more resources immediately to throw into battle than what could be obtained by relying only on current tax receipts. For example, Virginia's paper money Acts passed during the Seven Years' War (I755-62) stated:

And whereas, by reason of the long time allowed for collecting the duties imposed by this act, (Which, from the distressed circumstances of the people, and the great scarcity of gold and silver coin in this colony, could not be sooner done) the said duties will not be collected in time to answer the purposes [funding troops] hereby intended, Be it therefore enacted, That John Robinson, ... treasurer of this colony, ... is hereby authorized, and required to issue and emit so many treasury notes, as will be sufficient for the purposes aforesaid, ... (from the March 1756 Act, Hening 1969, vol. 7, p. 32, italics in original)

This process imparted a time-discounting dimension to the notes emitted. After 1756 , Virginia's notes paid no interest. They were, in effect, zero-coupon bonds. 
Several colonies south of New England, namely New York, New Jersey, Virginia, North Carolina and South Carolina, made their first paper money emissions interestbearing notes. The initial thinking being that the notes were borrowings and so paying interest was justified and required to get citizens to use them as a transacting medium in the marketplace. All these colonies quickly shifted to making their paper monies zero-coupon notes within a few years after these initial interestbearing emissions and for the most part made their paper monies zero-coupon notes thereafter (Grubb 20I6a, pp. 2I5-2I). Why they did this is not well articulated either by colonial writers at the time or in the modern secondary literature.

The best explanation seems to be that legislatures quickly realized that paying interest was not possible separate from the paper money's redemption tax structure. Colonial treasuries did not have revenue income with which to pay interest. What treasurers did was pay interest in the form of a discount off a citizen's tax bill. To redeem all the interest-bearing paper money emitted, they had to raise future tax bills to equal the face value of the paper money emitted plus the interest due on it. By doing this, the colony's citizens were in effect paying the taxes to pay themselves the interest, or were in effect borrowing from themselves and paying themselves back. As such, paying interest on notes was an unnecessary complication (Cutsail and Grubb 2017; Grubb 2016a, pp. I 56-7).

For example, suppose the legislature prints and pays you a $\mathrm{I} \mathcal{E}$, note this year and requires that note to be redeemed and removed from circulation via a tax payment by you next year. If the note is issued as a zero-coupon bond, the government would set next year's tax liability at I $\mathcal{E}$, and that would accomplish the redemption and removal as well as balance the intertemporal budget constraint. Now, suppose the note is an interest-bearing bond paying 6 percent annual interest. The government could accomplish the same balancing of the intertemporal budget constraint by setting next year's tax liability at I.06 $\mathcal{E}$ instead of I $\mathcal{E}$. These two scenarios looked equivalent to colonial legislatures, with the zero-coupon bond scenario looking easier to execute. While zero-coupon notes necessitated time-discounting in the marketplace when using the notes as a transacting medium of exchange, the zero-coupon feature was chosen because it eased the public finance and budgetary execution of the paper money laws by the legislature and its treasury.

While tax revenue monies are fungible, Virginia kept segregated treasury accounts so that taxes created to redeem and remove notes from circulation $(\mathrm{Tm})$ were not spendable revenue. Therefore, $M_{\mathrm{j}}=\sum T m_{\mathrm{t}}$ for years $\mathrm{t}=\mathrm{j}+\mathrm{I}$ through $N$. Other taxes $(T)$ were revenue taxes the government could directly spend. The legislature designed $T$ to cover the ongoing everyday expenses of government, often called 'support of government' expenses. These expenses included the salaries of provincial government officer holders and assemblymen, the other expenses of running the assembly, e.g. printing costs, and the other standard expenses involved in running the apparatus of government. In essence, $G$ was fully separated and segregated into normal everyday spending paid for by $T$, which was balanced in the budget on a yearly basis, and irregular and extraordinary spending related to war and warehouse 
fires paid by $M$, and so eventually paid for via $T m$, and balanced in the budget on an intertemporal basis.

The laws for $T$ and for $T m$ were separate and functioned differently. $T m$ were in each paper money emission Act. $T$ were separate tax laws. Regarding $T$ during the years covered by paper money emissions, Virginia's provincial government maintained import duties on liquor and slaves, and export duties on skins and furs. In what media these duties could be paid was not stated nor was what was used to pay them recorded in surviving documents. The main component of $T$, however, were tobacco taxes. Each county was responsible for collecting and paying its assemblymen so much tobacco as part of the assemblymen's salary and to cover assembly attendance expenses. The legislature also maintained a separate province-wide tobacco poll tax where each tithable was required to pay their respective county sheriff a legally established number of pounds of tobacco. The county sheriffs were required to gather and sell the tobacco and transfer the money to the colony's treasury. The law did not state in what media the tobacco could be sold. What media were actually transferred to the treasury is also unknown, not being recorded in the surviving documents (Hening I969, vol. 6, pp. I93-4, 470-I, 490-4, 496-9, 555-7; vol. 7, pp. 9-Іо, 56-7, I33-4, I35-6, I39-40, 265-73, 283-8, 290-2, 365-7, 386, 395-6, 405-6, 439-40, 476-7, 543-5, 585-6; vol. 8, pp. 38-4I, I78-82, I90-2, 237-8, 273-5, 335-6, 336-8, 340-2, 529-32, 533-4).

Not all citizens could make tobacco or acquire tobacco to pay these taxes and the legislature received petitions to pay tobacco taxes in money instead. Periodically, the legislature allowed tobacco taxes and tobacco debts to be paid at a fixed rate in money, at the option of the payer. They initially set the rate at $\mathrm{I} \mathcal{E V A}_{\mathrm{VA}}=200$ pounds of tobacco $={ }_{1} .25 \delta_{\mathrm{S}}\left[\delta_{\mathrm{VA}}=\right.$ Virginia paper pounds, $\mathcal{E}_{\mathrm{S}}=$ pounds sterling], but lowered it to $\mathrm{I}_{\mathcal{V} \mathrm{VA}}=\mathrm{I}_{2} \mathrm{O}$ pounds of tobacco $=\mathrm{I}_{25} 25 \mathrm{~S}$ in subsequent laws that allowed such payment substitutions (Hening I969, vol. 6, pp. 502, 568-9; vol. 8, pp. 38I-5).

Throughout the period covered by paper money emissions, the wholesale price of I 20 pounds of tobacco never averaged less than I NVA $_{\mathrm{VA}}$ in any year, and was often substantially more. Only in a few years in a few subregions of Virginia was it less than I fva (Carter et al. 2006, vol. 5, pp. 682-4). When allowed in law, this legal rate gave citizens an incentive to pay tobacco taxes in money. However, it appears from the tenor of the acts that most citizens paid the tobacco taxes in tobacco. The relatively low amounts of per capita paper money and specie money, estimated below, is consistent with citizens often making tobacco tax payments in tobacco and thus the primacy of barter in tobacco for domestic transactions in the Virginia economy.

The treasury accounts of colonial Virginia have not survived or yet been found. Thus, a full explication of the $T$ side of the public finance ledger is not yet possible. Fortunately, the portion of the treasury accounts that involved Tm were included in reports to the legislature and so recorded in the legislature's minutes. This information, given that $T$ and $T m$ functioned as separate and segregated accounts, along with the paper money laws, allows a full accounting of the paper money side of the public finance ledger, both $M$ and Tm. 
The typical method of $T m$ tax-redemption was to set net new taxes to redeem $M_{\mathrm{j}}$ to be an equal amount per year $\left(F m_{\mathrm{t}}\right)$ over an $N$-year redemption window, i.e. $\sum T m_{\mathrm{t}} / N=T m_{\mathrm{t}}$ for years $\mathrm{j}+_{\mathrm{I}}$ through $N$. The Virginia legislature took note redemption and its effect on controlling the value of its paper money seriously, as illustrated in the 1760 paper money Act that stated:

And whereas it is of the greatest importance to preserve the credit of the paper currency of this colony, and nothing can contribute more to that end than a due care to satisfy the publick that the paper bills of credit, or treasury-notes, are properly sunk, according to the true intent and meaning of the several acts of assembly passed for emitting the same; and the establishing a regular method for this purpose may prevent difficulties and confusion in settling the publick accounts, ... Be it therefore enacted ... That ... are hereby appointed a committee, to examine at least twice in every year...all such bills of credit, or treasury-notes, redeemable ... as have been or shall be paid into the treasury, in discharge of the duties and taxes imposed by any former act of assembly; and upon receipt of the said bills or notes, the said committee shall give to the treasurer for the time being a certificate of the amount thereof, which shall avail the said treasurer in the settlements of his accounts ... : And the said committee are hereby required and directed, so soon as they have given such certificate, to cause all such bills or notes to be burnt and destroyed. (Hening 1969, vol. 7, p. 353, italics in the original)

If $T m$ taxes were paid in $M$, then using the $F m_{\mathrm{t}}$ method removed $M_{\mathrm{j}}$ from circulation at a constant amount over the $\mathrm{N}$-year redemption window. If $\mathrm{Tm}$ taxes were paid by other means, e.g. in specie coins, then $M_{\mathrm{j}}$ would continue in circulation until year $N$, when it would be redeemed at face value and removed from circulation using the accumulated non-note tax receipts in the treasury. The language in the 1756 paper money Acts illustrates this redemption structure.

That the several sums of money and tobacco to be collected, by virtue of this act, ... shall be, ... paid to John Robinson, esquire, treasurer of this colony, ... That the money to be raised by the duties imposed by this act, shall stand, be, and remain as a security for the redemption of the said treasury notes so to be issued, and the said John Robinson, treasurer, ... is hereby required to apply all such money, as shall come to his hands, by virtue of this act, for, and toward the redemption of such treasury notes, and to no other use or purpose whatsoever. (Hening I969, vol. 7, pp. 19, 29, 32)

All of Virginia's paper money Acts had this language.

The face value of the notes for redemption purposes, and for paying the Tm taxes imposed to redeem the notes and remove them from circulation, was fixed in law

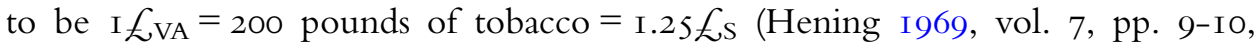
28-9). Initially the legislature set the tobacco equivalence at 240 pounds in 1755 before changing it to 200 pounds in 1756 and thereafter (Hening I969, vol. 6, pp. 46I-2). Throughout the period covered, however, the price of 200 pounds of tobacco was always greater than I $\mathcal{E}_{\mathrm{VA}}$, and often by substantial amounts (Carter et al. 2006, vol. 5, pp. 682-4). As such, there was a strong incentive not to pay the 
Tm taxes established in the paper money Acts and slated for note redemption in tobacco, but only in either notes or specie.

This was also a stronger incentive than that created by the option to pay $T$ tobacco taxes in money. For citizens who possessed paper money or specie coins, the incentive was to pay $T m$ taxes in paper money or coin first and $T$ tobacco taxes in paper money or coin second, if at all. Thus, while the preceding quotation mentioned Tm tax payments in 'money and tobacco,' non-note tax payments on the taxes enacted in the paper money Acts were likely only in specie. Why Virginia's legislature did this was not stated, but it would be consistent with trying to encourage tax payments into the note redemption accounts to be in notes or specie rather than in tobacco.

Table I compiles the paper money Acts passed by the Virginia legislature and lists the key features of each Act including the Tm taxes enacted. For a full accounting of the expected Tm revenues from I755 to I769, see Grubb (20I7, p. I0). Fifteen separate paper money Acts that involved net new emissions were passed, with a cumulative total of $484,963 \mathrm{E}_{\mathrm{VA}}$ in net new emissions made between 1755 and I774. Notes issued under different Acts could be distinguished by the Acts' emission dates printed on the notes (Newman 2008, pp. 437-57).

Paper money Acts began with statements about why monies were required, and in what amounts. Thirteen of the Is Acts stated that the money was required to cover military expenses. Paying for military expenses represented 90 percent of all net new paper monies emitted, and 98 percent of all net new paper monies emitted during the Seven Years' War. Emissions nos. 5 and is were used to compensate citizens who lost their tobacco in public warehouse fires. This compensation represented 8 percent of all net new paper monies emitted. Emission no. I4 was used to pay the expense of negotiating and establishing a boundary with the Cherokee Nation. It represented 2 percent of all net new paper monies emitted.

Paper money Acts then elucidated the particulars of how the money would be spent, and how the money would be redeemed (removed). Regarding spending, these particulars involved such things as military recruitment, fortification construction and how tobacco losses would be assessed. Regarding how the money would be redeemed, these particulars established the type of taxes, the tax rates and the taxing period to be used to redeem the money spent under the Act.

Every paper money Act listed a single date after which the Act's notes could be redeemed for specie on demand at the treasury. Redemption was at face value. In each paper money Act, that redemption date and the end of the taxing period imposed to redeem the money issued by that Act are a close match. Taxing and redemption are clearly linked. Per Act, the amounts of taxes imposed were expected to generate the sums needed to redeem all the notes emitted.

Table I also identifies three rule changes that altered prior paper money Acts. Emission no. 6 included a clause that required all outstanding notes of emissions nos. 2, 3 and 4, along with their accrued interest to that point, to be swapped for emission no. 6 notes. This swap removed any future interest payments attached to these prior emissions and altered the redemption dates of these prior emissions to that of 
Table I. Colonial Virginia's paper money (treasury notes) emissions based on statutory law, 1755-74

\begin{tabular}{|c|c|c|c|c|c|}
\hline Paper money Acts & $\begin{array}{l}\text { Emission } \\
\text { date printed } \\
\text { on the notes }\end{array}$ & $\begin{array}{c}\text { New } \\
\text { amount } \\
\text { emitted } \text { fva }_{\mathrm{va}}\end{array}$ & $\begin{array}{l}\text { Maturity } \\
\text { redemption } \\
\text { date }\end{array}$ & $\begin{array}{l}\text { New taxes, duties, and } \\
\text { fees imposed }(T m)\end{array}$ & Taxing period imposed \\
\hline no. $\mathrm{I}^{\mathrm{a}}$ & June I755 & 20,000 & 30 June 1756 & poll, land, slave import & June I 755 to Apr. I756 \\
\hline no. $2^{\mathrm{a}}$ & I I Dec. I755 & 40,000 & 30 June I76o & poll, land & Apr. I757 to Apr. I760 \\
\hline no. $3^{a}$ & Mar. I756 & 25,000 & 30 June I760 & poll, land & Apr. 1758 to Apr. 1760 \\
\hline no. $4^{a}$ & Mar. 1756 & 30,000 & 30 June 1760 & poll & Apr. I758 to Apr. I760 \\
\hline no. $5^{\mathrm{b}}$ & Mar. 1756 & IO,OOO & I5 Dec. I757 & tobacco export & Oct. 1756 to Oct. I 757 \\
\hline no. 6 & 8 June I757 & 84,963 & I Mar. I765 & $\begin{array}{l}\text { poll, land, tobacco } \\
\text { export and slave } \\
\text { import }\end{array}$ & Oct. I 757 to July I 765 \\
\hline \multicolumn{6}{|c|}{ [nos. 2,3 and $4\left(95,000 \mathcal{E}_{\mathrm{VA}}\right)$ swapped for new no. 6 notes] $]^{\mathrm{a}}$} \\
\hline no. 7 & I2 Apr. I758 & 32,000 & I Mar. I765 & poll, land & Apr. I76I to Apr. I764 \\
\hline no. 8 & I2 Oct. I758 & 57,000 & I4 Sept. I 766 & poll, land & Apr. I76I to Apr. I766 \\
\hline no. 9 & 5 Apr. I759 & 52,000 & 20 Apr. I768 & poll, tobacco export & Oct. I 764 to Oct. I 767 \\
\hline no. Io & 2I Nov. I759 & IO,000 & 20 Oct. 1769 & tobacco export & Oct. I 767 to Oct. I 769 \\
\hline no. II & I I Mar. I760 & 20,000 & Io Oct. I768 & poll, land & Apr. 1767 to Apr. I 768 \\
\hline no. 12 & 24 May I760 & 32,000 & 20 Oct. 1769 & poll, land & Apr. 1767 to Apr. 1769 \\
\hline \multicolumn{6}{|c|}{ [Rule change 3 Nov. I76I: New redemption date is 20 Oct. I769 for all notes currently in circulation.] ${ }^{c}$} \\
\hline no. I 3 & 7 Apr. I762 & 30,000 & 20 Oct. 1769 & poll & \multirow{2}{*}{$\begin{array}{l}\text { Apr. I764 to Apr. I769 } \\
\text { from Oct. I77I onward }\end{array}$} \\
\hline no. I4 & 7 Nov. 1769 & IO,000 & 2I Nov.I77I & $\begin{array}{l}\text { slave import, tobacco } \\
\text { export, carriage, } \\
\text { licence and writs }\end{array}$ & \\
\hline no. I5 & I I July I77I & 30,000 & Io Dec. I775 & $\begin{array}{l}\text { no.I } 4 \text { except for slave } \\
\text { import }\end{array}$ & from Oct. I77I onward \\
\hline
\end{tabular}


[Rule change 4 Mar. I773: replace $36,834 \mathcal{E V A}_{\mathrm{VA}}$ of no.I4 and no. I 5 and make their new redemption date I June I774] Total net new emissions: $484,963^{\mathrm{b}}$

${ }^{a}$ Emissions nos. I, 2, 3 and 4 paid 5 percent annual interest. This interest was suspended by the Act creating emission no. 6. Emissions nos. 2, 3 and 4 were swapped for emission no. 6 notes. The accrued interest outstanding to June I757 was paid by printing extra emission no. 6 notes. See Grubb (2017).

${ }^{\mathrm{b}}$ While statutory law only authorized I0,000 £ va for emission no. 5, I2,000 $\mathcal{N V A}_{\mathrm{VA}}$ was actually printed and emitted; see Grubb (20I7). Thus, $\mathrm{I} 2,000 \mathrm{fVA}_{\mathrm{VA}}$ is used as the correct amount for emission no. 5 in all subsequent analyses.

${ }^{\mathrm{c}}$ This Act was passed with a suspending clause. It was subsequently laid aside (suspended) by the Board of Trade, 4 February I 763 (Brock I 975 , pp. 488-9; Hening I969, vol. 7. p. 466; Journal of the Commissioners for Trade and Plantations, January I759- December I763 (1970), pp. 333-4). Sources: Grubb (20I7); Hening (I969, vol. 6, pp. 46I-8I, 52 I-30; vol. 7, pp. 9-25, 26-33, 46-54, 69-87, I63-9, I7I-9, 255-65, 33 I-7, 347-58, 357-63, 465-6, 493-502; vol. 8, pp. 342-8, 493-503, 647-5I); Newman (2008, pp. 437-57). 
emission no. 6 notes. On 3 November I76I, the legislature changed the redemption date for all notes currently in circulation, lengthening the redemption period to 20 October I769. This rule change, however, was passed with a suspending clause, and the Board of Trade laid it aside on 4 February I763 (Hening I969, vol. 7, p. 466; Journal of the Commissioners for Trade and Plantations, January I759 - December I763, pp. 333-4). Finally, the legislature on 4 March I773 replaced the notes still outstanding from emissions nos. I 4 and I 5 with new notes and changed their redemption date to I June I774. This note swap was intended to thwart counterfeiters.

All three rule changes did two things. Notes currently in circulation from different emissions with different final redemption dates had different present values. The rule changes made all notes currently in circulation have the same expected present value by giving them the same final redemption date. The legislature gave the following reason for these rules changes, 'it will be prejudicial to have notes of different value circulating at the same time' (Hening I969, vol. 7, p. 8I). All three rule changes were also an ex post facto altering of the expected present value of the notes affected, in most cases marginally reducing that present value from what it was under the original Act. The ex post facto reduction of the present value of notes in the I76I rule change contributed to its suspension by the Board of Trade. The Virginia legislature was combining the need to maintain fiscal credibility, by holding per year taxes at feasible levels via spreading redemptions out over more years, with the benefit of making all individual notes currently in circulation have a common expected present value thus making them an easier transacting medium to use. The legislature took the mechanics of their paper money system seriously and worked to make it function as well as possible under the constraints they faced.

Evaluating the overall performance of Virginia's paper money requires knowing the amount of notes in public circulation each year and the amount of notes redeemed (removed) from the public each year. A forensic accounting exercise is required to sort out this evidence. It cannot just be copied down from surviving documents, but must be reconstructed painstakingly from incomplete and discordant records. The exercise is like putting together a complex jigsaw puzzle with not all the pieces available. Grubb (20I7) provides the details of this exercise. Table 2 reports the data outcome. Table 2 also reports Virginia's white population.

The per white capita face value amount of notes in circulation peaked in 1760 at just under I.5 fVA. Before 1758 and after I764 it was under I fva. The maximum amount represented only 3.I to 4.I percent, and at I Eva per white capita only 2.0 to 2.6 percent, of the yearly compensation paid to free workers in Philadelphia in the early I770s (Grubb 20II, pp. 260-I). The Tm payments are estimated to be between 60 and 75 percent in notes and the rest in specie coins (Grubb 20I7, pp. IO-I I), implying an even smaller per white capita amount of specie money than paper money. Thus, even with the emission of large amounts of paper money, the domestic economy was still under-monetized with transactions often executed through efficient barter structures such as with book and store credits and with tobacco. 
Table 2. Reconstruction of colonial Virginia's paper money regime, 1755-75

(I)

Year
(2)

Net new notes emitted to the public each year
(3)

Resulting Notes redeemed from the public each year $\left(M_{\mathrm{t}}\right)$
(4) (5) Virginia's white notes in public revenues in the treasury circulation earmarked to redeem notes at population $^{c}$ their final legislated redemption date

\begin{tabular}{|c|c|c|c|c|c|}
\hline & Eva & Eva & Eva & Eva & \\
\hline I755 & $37, \mathrm{I} 79$ & o & $37, \mathrm{I} 79$ & $\mathrm{I}, 860$ & I 64,369 \\
\hline I756 & 74,336 & I 5,932 & 95,583 & 9,294 & I 71,326 \\
\hline I757 & 85,753 & I3,73 I & I67,605 & I 3,740 & I 76,284 \\
\hline I758 & $8 \mathrm{I}, 83 \mathrm{I}$ & 26 , I I 8 & 223,3 I 8 & 22,196 & I $85,24 \mathrm{I}$ \\
\hline I759 & 69,749 & $26, \mathrm{II} 8$ & 266,949 & 30,652 & I92,I99 \\
\hline I760 & 53,999 & 24,682 & 296,266 & 39,108 & I99, I 56 \\
\hline I76I & 5,244 & 28,003 & 273,507 & 48,640 & $205, \mathrm{I} 82$ \\
\hline I 762 & I9,782 & 28,003 & 265,286 & $58, \mathrm{I} 72$ & 211,207 \\
\hline I 763 & IO,627 & 22,793 & $253, \mathrm{I} 20$ & 73,548 & 217,233 \\
\hline I 764 & 2,502 & 26,300 & 229,322 & 9I, I 74 & 223,258 \\
\hline I 765 & o & I6,949 & $2 \mathrm{I} 2,373$ & $\mathrm{IO} 2,800$ & 229,284 \\
\hline I 766 & o & $\mathrm{I} 9, \mathrm{I} 48$ & I93,225 & I IO, $622^{\mathrm{a}}$ & 235,309 \\
\hline I 767 & o & $25,75 \mathrm{I}$ & I 67,474 & IO,5 I9 & $24 \mathrm{I}, 335$ \\
\hline I 768 & o & $25,75 \mathrm{I}$ & I 4I, 723 & $2 \mathrm{I}, 039$ & 247,360 \\
\hline I 769 & IO,OOO & $2 \mathrm{I}, 046$ & І 30,677 & 29,636 & 253,386 \\
\hline I 770 & $\mathrm{o}$ & IO,54I & I 20, I 36 & $8,56 \mathrm{I}$ & 259,4 I I \\
\hline I77 I & 30,000 & IO,944 & I 39, I92 & I 6,7 I 2 & $265,2 \mathrm{I} 2$ \\
\hline I 772 & o & 36,562 & IO2,630 & 7,366 & 27I,OI 3 \\
\hline I 773 & o & 36,562 & 66,068 & 5,554 & 276,8 I 4 \\
\hline I 774 & o & 23,355 & $42,7 \mathrm{I} 3$ & 3,742 & 282,6 I 5 \\
\hline I 775 & $o^{b}$ & 2,763 & 39,950 & I,930 & $288,4 \mathrm{I} 7$ \\
\hline Totals & $48 \mathrm{I}, 002$ & $44 \mathrm{I}, 052$ & & & \\
\hline
\end{tabular}

${ }^{a}$ The accumulated non-note revenues in 1766 are based on expected tax revenues, reduced by I 2 percent to get the actual accumulated sum to account for accumulating tax arrears of about 3 percent over the period. These are also the sums removed from the treasury by John Robinson, which he loaned to his friends. Robinson died on I I May I766. Of the amounts Robinson removed from the treasury were $95,828 \mathrm{fvA}$ of accumulated taxes held for redemption of notes when said notes' circulation time was at an end. In I 766 , it was recorded that only $2,2 \mathrm{I} 8 \mathrm{f}_{\mathrm{VA}}$ was left in the treasury to pass on to the new treasurer after Robinson's death. The closeness of the $95,828 \mathcal{E V A}_{\mathrm{VA}}$ figure to what would have accumulated in the treasury in 1766 , namely $\left(110,622 \mathrm{fVA}_{\mathrm{VA}}-2,2 \mathrm{I} 8 \mathrm{fVA}_{\mathrm{VA}}\right)=108,404 \mathrm{fVA}_{\mathrm{VA}}$ provides support for the data construction. See Grubb (2017).

${ }^{\mathrm{b}}$ Excludes net new emissions late in I775. See Newman (2008, pp. 444-6).

${ }^{c}$ Interpolated values between decadal benchmarks are used. Derived from Carter et al. (2006, vol. 5 , p. 652).

Sources: Table I; Carter et al. (2006, vol. 5, p. 652); Grubb (2017); Kennedy (1906a, pp. xi-xxv, 64-6, I08, II 8-20, I24-8, I54-6, 283-5, 303; I906b, pp. 72, 2I7-I8; I907, pp. I43, I7I, I76-8, 356-7); McIlwaine (I908, pp. I5, 36-7, I I5-I6, I7I-2, 249-50; I909, pp. 388, 458, 487-90); William and Mary College Quarterly Historical Magazine (I9I2), pp. 227-62. 
Column 4 of Table 2 estimates the accumulated amount of non-note tax revenues, primarily specie coins, in the treasury that were to be used to redeem notes at their final legislated redemption dates. These amounts are needed, along with the amounts in column 2, to estimate the real-asset present value of the notes. The amounts in column 4 need to be adjusted further to account for the fact that John Robinson, the treasurer, removed the amount that had accumulated in I766 by loaning these sums out to friends. This action was considered irregular and constituted possible malfeasance. It created a scandal and the possibility that notes could not be redeemed when they came due at the treasury. Suspicions that malfeasance was going on affected the expected real-asset present value of the notes in the years immediately prior to $\mathrm{I} 766$.

When notes became redeemable at the treasury for the tax monies accumulated, they were not always immediately redeemed. The monies held in the treasury for their redemption continued to be held for that purpose. These notes continued in circulation and, at this point, took on a redeemable-upon-demand quality with Ioo percent reserve-backing in the treasury.

For example, emission no. 5 was redeemable at the treasury at the end of 1757 , but was not all redeemed until I 766 . The tax monies received in 1757 for its redemption continued to be held in the treasury for future redemption of emission no. 5 notes (Grubb 20 I7). Robert Carter Nicholas, treasurer after I766, observed similar behavior. In I773, he noted, 'Most of the Merchants as well as others, ... preferred them [Virginia's notes] either to Gold or Silver, as being more convenient for transacting the internal Business of the Country' (William and Mary College Quarterly Historical Magazine I9I2, p. 235). Note the use of the term 'internal'. Specie coins had a positive opportunity cost when used for domestic transactions. As such, domestic transactions typically used inside paper monies and efficient barter structures. Imported specie coins typically bought imported goods, thereby re-exiting the colony (Grubb 2012).

\section{III}

I apply a decomposition approach to evaluate Virginia's paper money performance (Celia and Grubb 20I6, pp. II48-9; Cutsail and Grubb 20I7; Grubb 20I6b, pp. I2 I7-I8). The observable market exchange value (MEV) of this money is decomposed into its component parts; see equation (2). $M E V$ equals its expected real-asset present value $(A P V-R D)$, i.e. its value as just another non-money barter asset, plus its transaction premium $(T P)$ that measures its pure 'moneyness' value, i.e. its extra value as a transacting medium of exchange. Positive values for TP measure the willingness of the public to pay a premium above the notes' expected real-asset present value, because the notes served as a more convenient transacting medium than the next best barter alternative. The expected real-asset present value is further separated into its pure time-discounting component $(A P V)$, and its default risk component $(R D)$. All components in equation (2) are calculated as a percentage of face value to be in 
a comparable metric.

$$
M E V_{t} \equiv(A P V-R D)_{t}+T P_{t}
$$

The legislature controlled $A P V$ and $R D$. It controlled $A P V$ by choosing the redemption structure, and it influenced $R D$ by how it executed those redemption structures. TP was determined by the public through the structure of the economy in terms of how the public evaluated and used alternative media of exchange to execute domestic transactions.

Empirical measurement is the difficult part of applying this approach. While one can measure $M E V$ using data on exchange rates to an outside money, $R D$ and TP cannot be independently measured. In addition, measuring $A P V$ entails constructing a counterfactual value of the notes, namely their value when not used as money and when no risk of default is expected.

Fortunately, Virginia's treasury notes were structured as zero-coupon bonds, except for the 1755 and 1756 emissions which were structured as interest-bearing bonds (Grubb 20I6a, 2017; Hutchinson and Rachal I962, vol. I, pp. 305-6; Labaree I959-70, vol. II, pp. I3-I5; Smith I937, pp. 310-I2). The notes had legally defined maturity dates when they could be redeemed at face value in specie equivalents by Virginia's government, and they could be redeemed at face value for $T m$ tax payments due any time after initial emission. Given expected redemption time-paths, maturity dates, payoff values and an appropriate risk-free time-discount rate, the $A P V$ of these notes as risk-free non-money tradable bonds can be calculated independent of their $M E V$.

Moving the variables that can be independently measured to the left-hand side, and the variables that cannot be independently measured to the right-hand side, yields equation (3). In terms of proportions, the ratio $A P V_{\mathrm{t}} / M E V_{\mathrm{t}}$ shows how much of $M E V_{\mathrm{t}}$ is accounted for by $A P V_{\mathrm{t}}$ with the residual share being accounted for by $(T P-R D)_{\mathrm{t}}$. The gap between $M E V_{\mathrm{t}}$ and $A P V_{\mathrm{t}}$, measures the magnitude of $(T P-R D)_{\mathrm{t}}$.

$$
\left(M E V_{\mathrm{t}}-A P V_{\mathrm{t}}\right) \equiv(T P-R D)_{\mathrm{t}}
$$

The possibility that $T P_{\mathrm{t}}$ and $R D_{\mathrm{t}}$ are both greater than zero by large magnitudes at the same time is unlikely. Behaviorally, $T P$ is likely to be a negative function of $R D$. Thus, as $R D$ takes on positive values, $T P$ is quickly driven to zero. An asset with a high default risk is unlikely to possess a transaction premium, i.e. be the preferred medium of exchange, relative to an asset with a low default risk. Therefore, I assume that when $(T P-R D)_{\mathrm{t}}>\mathrm{o}$, it is primarily due to $T P_{\mathrm{t}}>\mathrm{O}$; and when $(T P-R D)_{\mathrm{t}}<\mathrm{o}$, it is primarily due to $R D_{\mathrm{t}}>$ o.

To apply equation (3), two data sets are required. I compile the market exchange value (MEV) of Virginia's notes between I755 and I774, and I calculate the counterfactual expected real-asset present value $(A P V)$ of Virginia's notes as non-money lowrisk bonds. I use the observed market exchange rates between Virginia's notes and bills 
of exchange paying pounds sterling in London to construct $M E V$. These exchange rates are primarily from merchant account books and are expressed as the face value amount of Virginia notes needed to buy, in Virginia, a Ioo pound sterling bill of exchange drawn on London (McCusker I978, pp. 205-I4).

I adjusted these exchange rates to account for the cost of getting a bill of exchange to London and getting it liquidated into specie usable in Virginia. I estimated that cost to be 7.09 percent (Grubb 20I6a, p. I79). Thus, the realized par exchange rate of a Virginia note is I I6.I4 $\mathcal{E V A}_{\mathrm{VA}}={ }_{\mathrm{IOO}} \mathrm{f} \mathrm{s}$ compared with the legal par exchange rate of $\mathrm{I} 25 \mathcal{E}_{\mathrm{VA}}={ }_{100} \mathcal{L}_{\mathrm{S}}$ (Hening I969, vol. 6, pp. 478-83). MEV is calculated by dividing this adjusted number (I I6.I4) by the observed exchange rates in McCusker (I978, pp. 2II-I2). MEV measures the spot-market conversion in Virginia of Virginia paper pounds into a silver commodity outside money expressed as a percentage of the face value of Virginia paper pounds.

Virginia's paper money had a bearer-bond quality that required an explicit redemption exercise to extinguish the principal expressed on the note's face. Virginia's citizens are assumed to act as if they understood their paper money to be interest-bearing bonds in 1755 and 1756 , and zero-coupon bonds thereafter, requiring time-discounting to ascertain their present value (their $A P V$ ), and to know how to calculate this value (Labaree I959-70, vol. I I, pp. I3-I5; Ricord I 892, vol. I7, p. I59; Smith I937, pp. 3IO-I2). The public is also assumed to know the quantity of notes in circulation $\left(M_{\mathrm{j}}\right)$ and the amounts redeemed $\left(R E D_{\mathrm{t}}\right)$ each year as shown in Table 2. $R E D_{\mathrm{t}}$ includes the amount of funds (specie) in the treasury that could be used for redemption at face value at the end maturity dates of the notes as shown in Tables I and 2.

For the most part, the evidence does not record what notes from which emissions were redeemed when, but lumps redeemed notes from all emissions currently outstanding together (Grubb 20I7). For this reason, I assume that the public responded only to the expected redemption of the average note currently outstanding. Because the $M E V$ data only measure the current market value of the average note in circulation, and do not distinguish between the notes of different emissions, $A P V$ is calculated to be a comparable measure to $M E V$.

Equation (4) shows how I calculate the expected $A P V$ of the average note in circulation. It is adapted from the basic continuous discounting present value formula $\left(\mathrm{PV}=\mathrm{FV} e^{-r t}\right)$, where $\mathrm{PV}$ is present value, $\mathrm{FV}$ is face value, $r$ is the discount rate and $t$ is the time to maturity. In Equation (4) the amount of Virginia paper money outstanding in a given year is assumed to be redeemed by all notes actually redeemed in the immediately following years, including the potential redemption at the end maturity date using accumulated specie in the treasury, until the year when that original amount is fully redeemed. These yearly redemption amounts are divided by the initial amount outstanding from the chosen year to assign a yearly weight to its contribution in the redemption process. The time discounts between the initial year and the redemption year are multiplied by the contribution-weights for their respective years. The time-discount-weight values for each year are summed to get the 
expected present value of a representative note outstanding for that chosen year. The $A P V$ calculation is adjusted for 1755 and 1756 to account for the interest actually paid (Grubb 20I7).

$$
A P V_{j}=\sum_{\mathrm{t}=\mathrm{j}}^{N}\left(R E D_{t} / M_{j}\right) e^{-r t .}
$$

Where $r=$ the risk-free time-discount rate or opportunity cost of capital, $M_{\mathrm{j}}=$ the face value amount of Virginia paper money outstanding in year $\mathrm{j}, R E D_{\mathrm{t}}=$ the face value amount of Virginia notes redeemed and retired from circulation each year, including the amount of funds (specie) in the treasury that could be used for redemption at face value at the end maturity dates of the notes, with $R E D_{N}$ being the amount in the last year $N$ that satisfies:

$$
\sum_{i=j}^{N}\left(R E D_{t} / M_{j}\right)=1
$$

No time-series of market-generated interest rates for any class of assets currently exists for colonial America. Therefore, I use the $r$ considered normal by colonial contemporaries for assets with relatively low default expectations. This rate is a proxy for what in modern analysis is the risk-free rate. In I748, the Virginia assembly set the legal interest rate for the colony at 5 percent, where it stayed for the rest of the colonial period. However, the legislature indicated that the market rate was above this legal rate (Hening I969, vol. 6, pp. IOI-4). In I764, Benjamin Franklin stated that the rate for discounting well-funded legislature-issued zero-coupon bonds was 5 or 6 percent (Labaree 1959-70, vol. I I, pp. I3-I5). The interest rate mentioned most often for the middle colonies in the second half of the eighteenth century was 6 percent (Grubb 20I6a, pp. I63-4). Given uncertainty over the exact rate, an $r$ from 5 through 7 percent is used, with 6 percent being my best guess. A risk-adjusted $r^{\star}$ rate for Virginia's treasury notes will also be imputed, namely a rate that can range above the risk-free rate (see Figure 2 below).

\section{IV}

Figure I compares the levels of $M E V$ and $A P V$ over time, when $A P V$ is discounted at 5,6 and 7 percent. $M E V$ could be within a couple of percentage points of that drawn due to measurement error, and while 6 percent is my best-guess discount rate, uncertainty over that rate means that 5 or 7 percent could also be used. Considering the range of possible measurement errors, the hypothesis that $M E V$ is predominantly comprised of $A P V$ cannot be rejected given the data in Figure I. Little $(T P-R D)$ figures in to $M E V$. Virginia treasury notes were not a fiat currency. They were predominantly real barter assets. 


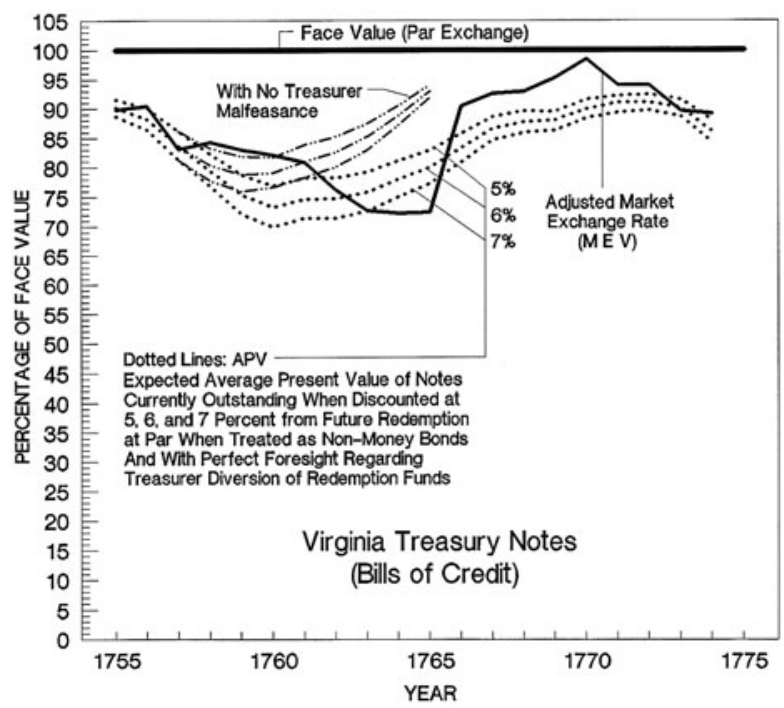

Figure I. $M E V$ versus $A P V, 1755-74$

Notes: See text for construction.

Sources: Grubb (20I7) and Table 2 using equation (4).

Using $M E V$ as drawn and the best-guess 6 percent discount rate over the entire period covered by colonial Virginia's paper money regime $A P V$ accounts for 97 percent of $M E V$, leaving $T P$ to account for 3 percent of $M E V$. Within this overall span, four subperiods can be identified. $M E V \approx A P V$ from I755 through I757, implying that $(T P-R D) \approx 0$ during the initial three years of Virginia's paper money regime. Being a new endeavor for Virginia, the notes possessing no TP in these initial years is not surprising.

By comparison, $M E V>A P V$, implying that $R D \approx 0$ and $T P>0$, in the years I758-62 and I766-74. The years I758-62 and I766-72 appear to be normal in that no specific financial crises are identifiable. In these years, $A P V$ accounts for 93 to 94 percent of $M E V$ leaving TP to account for 6 to 7 percent of $M E V$. While relatively small, this TP was enough to make Virginia's treasury notes the preferred medium of exchange for executing domestic trades. This 6 to 7 percent can be considered a measure of the transaction cost gains from using notes, compared with using book credit, tobacco claims, or specie, to execute domestic trades.

In the subperiod $\mathrm{I}_{763-5}, M E V<A P V$, implying that $T P \approx \mathrm{O}$ and $R D>0$. This period is associated with a financial crisis that preoccupied Virginia politics. John Robinson, Treasurer and Speaker of the House from I73 8 until his death in early I766, had been suspected of diverting funds accumulating in the treasury, funds earmarked for redeeming notes at their end maturity dates. He loaned these funds, without specific authority to do so, to his friends. In I766, after his death, just over 95,000 f,va of these funds were discovered to have been so diverted. Given the 
large amount diverted, the suspicions expressed at the time that malfeasance was happening seem credible (Ernst I973, pp. I77, I83, I 88; Lee I825, pp. 22-3; Mays I952, pp. I75, I $8 \mathrm{I}$ ). The evidence in Figure $\mathrm{I}$ is consistent with the public becoming suspicious of improprieties around I76I, judging by the shrinking TP that starts after I760. (TP $-R D)$ does not become negative until I763, which is consistent with the public definitely responding to something being amiss at the treasury regarding potential note non-redemption.

Given that a substantial amount of notes in circulation in the early I 760 s had their end maturity dates between I765 and I769, see Table I, the public had to be concerned in the early I 760 s that the accumulating tax funds in the treasury earmarked to redeem these notes would not be there when so required for redemption. A letter in the Virginia Gazette, I7 October I766, remarked that 'Many of us, to our great detriment, have had money paid to us whose day of redemption was elapsed, and which some of our creditors refused to receive from us again, alleging it was no currency; this money, when carried to the Treasury has frequently been refused to be redeemed, under the pretense that the Treasury was empty ...' Fear of delayed redemption led the public to eliminate any TP and then add a positive $R D$ to the notes by I763. The data in Figure I, using the best-guess 6 percent discount rate, indicate that the $R D$ in $1763-66$, assuming $T P \approx 0$, accounted for an average of 7.5 percent of $M E V$. In other words, $M E V=(A P V-R D)$ in these years. The notes in this period functioned like risky barter assets.

Figure I illustrates what the $A P V$ would have been if there was no diversion of treasury funds, with those funds remaining in the treasury to execute note redemption as legislated. Between I 763 and I765, using the best-guess 6 percent discount rate, $A P V$ would have been I I percentage points higher with no treasurer diversion of redemption funds. I construct a counterfactual $M E V$ for the years I 763-5 using this alternative higher $A P V$ by assuming $M E V=(A P V+T P)$, where the $T P$ is taken from the prior normal years of $1758-62$, and $R D$ is assumed to be zero. In the absence of treasurer malfeasance, $M E V$ would have averaged 96 percent of face value in $1763-5$ as opposed to its actual 72 percent of face value - a 24 percentage point effect on $M E V$. The treasurer's diversion of redemption funds fully accounts for the exchange rate crisis of the early I760s (Ernst I973, p. I94).

After Robinson died in early I766 and his actions were fully documented, $M E V$ and $A P V$ rapidly returned to normal patterns. Robinson's estate was required to repay the sums diverted. The repayment of these funds, and the resumption of normal tax payments and use of the specie portion to redeem notes, meant the return to normal expected redemption processes.

Early in I773, notes of the I769 and I77I emissions were discovered to have been counterfeited 'in so ingenious and dangerous a manner that it is difficult to distinguish the forged from the good bills' (Hening I969, vol. 8, p. 648; Kennedy I905, pp. viiixi, 7, 9-IO, 26-7). The assembly moved swiftly to mitigate the impact. They required all notes from emissions nos. I 4 and I 5 still outstanding to be swapped for new notes in I773, and hunted down the counterfeiters (Hening I969, vol. 8, pp. 647-5I; 
Kennedy I905, pp. viii-xi, 7, 9-IO, I5-I6, I8-20, 23-4, 27, 29-32, 35, 264). If the public expected the actions of the assembly to be ineffectual, they would have discounted the notes severely, i.e. generated a $R D>0$, to account for the risk that not all notes could now be redeemed as legislatively promised (Ernst I973, pp. 33 I-4).

Figure I shows that this counterfeiting scare, while a topic of public discussion and legislative action, had little impact on the value of the notes in circulation. Using the best-guess 6 percent discount rate, $M E V$ exceeds $A P V$ in 1772 and $\mathrm{I} 774$ by the normal $T P$ amounts. In $\mathrm{I} 773, M E V \approx A P V$, thus leaving $(T P-R D) \approx 0$. No significant $R D>0$ appears in this period. At best, a 4 to 6 percentage point dip and then return in TP occurs from $\mathrm{I} 772$ to $\mathrm{I} 773$ to $\mathrm{I} 774$.

This result is important because stories of counterfeiting have given the impression that colonial bills of credit were problematic paper monies or even worthless monies (Ernst I973, pp. 33 I-4; Scott I957). The evidence in Figure I indicates that counterfeiting had a minor and temporary economic impact on the value of Virginia's paper money. While this is the first systematic quantitative measure of the impact of a significant counterfeiting episode on the value of colonial paper monies, it raises the possibility that counterfeiting is an over-dramatized topic. Colonial governments had the tools to mitigate the impact of counterfeiting quickly and almost completely, and they employed these tools when necessary.

I employ an alternative risk-adjustment method to get at the same issues. If $T P=0$, then $M E V$ measures the current spot market value of these notes as non-money bonds. Given the expected redemption structure, the interest rate $r^{\star}$ that makes $M E V=(A P V-R D)$ is calculated, i.e. select $r^{\star}$ such that $M E V_{\mathrm{j}}=\sum_{\mathrm{t}=\mathrm{j}}^{N}\left(R E D_{\mathrm{t}} / M_{\mathrm{j}}\right)$ $e^{-r^{\star t}}$. If in fact $T P=\mathrm{o}$, then $r^{\star}$ would be the first time-series of market-generated interest rates for any class of assets in colonial America.

If $r \star$ is within the normal range of risk-free discount rates, then the proposition that the notes are simply non-money barter assets with no special 'moneyness' value or fiat currency attributes cannot be rejected. If $r^{\star}$ is above this range, then the notes are risky non-money bonds. If $r \star$ is below this range, then the proposition that $R D \approx 0$ and TP $>0$, namely that the bills have some 'moneyness' value, cannot be rejected. The magnitude by which $r^{\star}$ is outside the normal range of risk-free interest rates measures the extent that $R D>0$ when $r \star$ is above that range, and the extent that $T P>0$ when $r \star$ is below that range.

Figure 2 displays $r *$ from I755 through I774 along with the legal interest rate and my best-guess normal risk-free rate of 6 percent. In the first three years of the paper money regime, I755-7, $r^{\star}$ is around the normal range of risk-free discount rates, implying that the notes' $M E V$ is largely determined by $A P V$. The notes are primarily a low risk barter asset in these years.

The imputed $r^{\star}$ drops well below the risk-free discount rate from 1758 through I762, and again from I766 through I772. These below-normal $r *$ rates do not represent the normal market rate being driven down by an increased emission of paper money. No contemporary writer or any other evidence indicates that normal interest rates were as low as $r^{\star}$ in these years, and in the second period the amount 


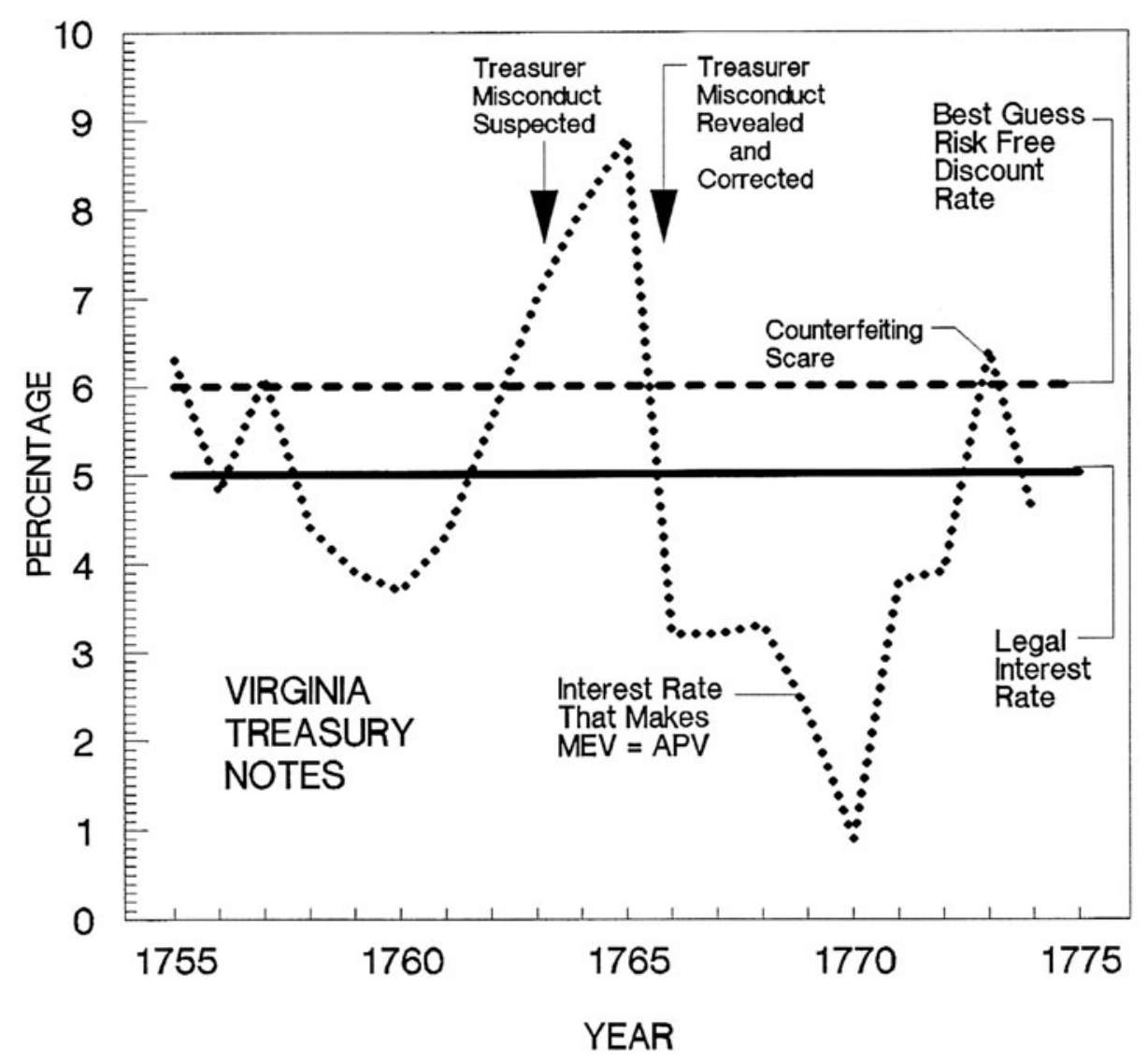

Figure 2. $r^{\star}$ through time, $1755-74$

Notes: See text for construction.

of notes in circulation experienced substantial contraction not expansion; see Table 2. In other words, the proposition, $T P>0$, cannot be rejected in these years.

Figure 2 also shows the periods when $R D>0$ due to suspicion of potential nonredemption. The malfeasance suspected and then revealed at the treasury between I 763 and I766 appears as a spike in $r^{\star}$, reaching 9 percent by 1765 before returning to its typical non-crisis range thereafter. Because no evidence indicates that riskfree discount rates were ever in the 9 percent range in this period, this finding implies that $T P \approx 0$ and $R D>0$ in these years. The notes were risky barter assets in these years. Figure 2 also shows the relatively minor nature of the counterfeiting scare in I773. While the scare briefly eliminated any $T P>0$ attached to the notes, their use remained in the range of free-risk barter assets, rather than risky barter assets.

The results in Figures I and 2 also indicate that the Seven Years' War (I755-62) had a limited effect on Virginia's public finances in terms of its paper money performance. 
The Seven Years' War disrupted Virginia's transatlantic trade and led Virginia to emit massive amounts of paper money to fund its participation in that war; see Table I. In spite of this, Virginia was able to manage its paper money regime reasonably well (Wicker I985). The massive expansion in paper money occasioned only a Io percentage-point decline in Virginia's paper money value during the war, roughly from 90 to 80 percent of face value. The paper money's value recovered thereafter, especially when netting out the treasurer's malfeasance via the counterfactual exercise employed here. Virginia was able to achieve this outcome by the way in which they structured and executed the future redemptions of their wartime paper money emissions. In I 760, Virginia began to substantially contract the amount of paper money in circulation via redemption in excess of new emissions; see Table I. The public assisted this outcome by adding 'moneyness' value $(T P)$ to the paper money's time-discounted asset present value as part of the public's response to Virginia's under-monetized economy.

Table 3 reports the time series statistical properties of $M E V$ and $A P V$, using the bestguess 6 percent discount rate for $A P V . M E V$ is a trend stationary series, with a structural break at I766. $A P V$ is a stationary series with a structural break at I 766. Both have short half-lives to shocks. $M E V$ and $A P V$ are also cointegrated. Thus, estimating $A P V$ 's effect on $M E V$ over time is a valid exercise. Panel $\mathrm{C}$ in Table 3 reports that effect. $A P V_{\mathrm{t}}$ has a statistically significant positive effect on $M E V_{\mathrm{t}}$ with a relatively large coefficient magnitude. Statistically, $A P V$ and $M E V$ are closely associated. $\triangle M E V$ tracks $\triangle A P V$ through time.

The unbiased coefficient on $A P V \sigma_{\mathrm{t}}$ in Table 3 panel C, namely uncorrected for serial correlation with no lags of the dependent variable included, is 0.96 , which is close to I.o indicating a tight relationship between $M E V$ and $A P V 6$, namely APV6 explains 96 percent of $M E V$. The constant term in the regression is $(T P-R D)$, derived from equation (2). The unbiased coefficient on the constant term is a positive 5.8. This indicates that over the entire sample $T P>0$ and explains close to 6 percent of $M E V$, close to that derived from the raw data in Figure I.

I estimate the determinants of TP in Table 3 panel $D$. $(T P-R D)_{t}$ is measured by $(M E V-A P V)_{\mathrm{t}}$, see equation (3). Because $(T P-R D)$ cannot be decomposed empirically, careful interpretation of the independent variables is required to assess $\triangle T P$ versus $\triangle R D$. Because $T P$ is likely to be a negative function of $R D$, with $T P$ quickly driven to zero when $R D$ takes on positive values, positive independent variables are capturing positive movements in TP.

The I766 structural break is significantly associated with higher TP thereafter; see also Figure I. The structural break captures the shift from the old treasurer, John Robinson, who was suspected of malfeasance, to a new treasurer, Robert Carter Nicholas. This transition removed the $R D$ that arose in the early I 760 s caused by suspicions that Robinson had misappropriated specie in the treasury that was to be used to redeem notes. 
Table 3. Statistical properties and determinants of $M E V$ and $A P V, 1755^{-74}$

\begin{tabular}{|c|c|c|c|c|c|c|c|c|}
\hline & & & & \multicolumn{4}{|c|}{ Adjusted } & \multirow{2}{*}{$\begin{array}{l}\text { Half-life } \\
\text { in years }\end{array}$} \\
\hline & & & & Lags & $N$ & $R^{2}$ & $F$ & \\
\hline \multicolumn{9}{|c|}{ Panel $A . M E V$ stationarity test: $\left(M E V_{\mathrm{t}}-M E V_{\mathrm{t}-\mathrm{I}}\right)=$} \\
\hline $\begin{array}{l}\text { I } 339.1400^{\star \star \star} \\
(433.555 \mathrm{I})\end{array}$ & $\begin{array}{l}-0.5955\left(M E V_{\mathrm{t}-\mathrm{I}}\right) \star \star \star \\
\text { (O.I I IO) }\end{array}$ & $\begin{array}{l}-0.734 \mathrm{I}(Y E A R)^{\star \star \star} \\
(0.2450)\end{array}$ & $\begin{array}{l}+\mathrm{I} 7.0 \mathrm{I} 78(D)^{\star \star \star} \\
\quad(3 . \mathrm{I} 83 \mathrm{I})\end{array}$ & o & I9 & 0.67 & $\mathrm{I} 3.75^{\star \star \star}$ & 0.77 \\
\hline \multicolumn{9}{|c|}{ Panel B. $A P V 6_{\text {stationarity test: }\left(A P V 6_{\mathrm{t}}-A P V 6_{\mathrm{t}-\mathrm{I}}\right)=}$} \\
\hline $\begin{array}{l}23.7956^{\star \star \star} \\
(5.8349)\end{array}$ & $\begin{array}{l}-0.3049\left(A P V 6_{\mathrm{t}-\mathrm{I}}\right)^{\star \star \star} \\
(0.0756)\end{array}$ & $\begin{array}{l}+2.6552(D) \star \star \\
(\text { I.1219) }\end{array}$ & & I & I 8 & 0.79 & $22.32^{\star \star \star}$ & I.9I \\
\hline \multicolumn{9}{|c|}{ Panel C. $M E V_{\mathrm{t}}$ versus $A P V \sigma_{\mathrm{t}}: M E V_{\mathrm{t}}=$} \\
\hline $\begin{array}{l}5.7669 \\
(\mathrm{I} 4.4955)\end{array}$ & $\begin{array}{l}+0.9606\left(A P V 6_{\mathrm{t}}\right) \star \star \star \\
(0.17 \mathrm{I} 6)\end{array}$ & & & o & 20 & 0.60 & $31 \cdot 33^{\star \star \star}$ & \\
\hline $\begin{array}{l}-5.7297 \\
(\mathrm{I} 3.4 \mathrm{I} 29)\end{array}$ & $\begin{array}{l}+0.6580\left(A P V 6_{\mathrm{t}}\right)^{\star \star} \\
(0.2426)\end{array}$ & $+z_{\mathrm{t}}$ & & I & I9 & 0.73 & $25 \cdot 40^{\star \star \star}$ & \\
\hline Cointegration test: $\left[z_{\mathrm{t}}-z_{\mathrm{t}-\mathrm{I}}\right]=$ & $\begin{array}{l}0.0324 \\
(0.9957)\end{array}$ & $\begin{array}{l}-0.8342\left(z_{\mathrm{t}-\mathrm{I}}\right)^{\star \star} \\
(0.2464)\end{array}$ & & o & I 8 & 0.38 & I I. $46^{\star \star \star}$ & 0.38 \\
\hline
\end{tabular}




\begin{tabular}{cccccc} 
& & Adjusted & & $\begin{array}{c}\text { Half-life } \\
\text { in years }\end{array}$ \\
\cline { 1 - 2 } Lags & $N$ & $R^{2}$ & $F$ &
\end{tabular}

Panel D. Transaction premium determinants: $\left(M E V_{\mathrm{t}}-A P V 6_{\mathrm{t}}\right)=\left(T P_{\mathrm{t}}-R D_{\mathrm{t}}\right)=$
$-8.8639^{\star}$
$+8.4926\left(M_{\mathrm{t}} / P_{o p}\right)^{\star \star}$
$+8.34 \mathrm{I} 3(D) \star \star$
I
I9 0.42
$5 \cdot 34^{\star \star}$
(4.2843)
(3.7650)
(3.02 I3)

Notes: Data are annual. Standard errors are in parentheses under their respective coefficients. Lags refers to lagged dependent variables included to removal serial correlation. $A P V 6=A P V$ when discounted at 6 percent. $D$ is a structural break dummy variable capturing the change in treasurers and so the end of the diversion of redemption funds, see the text. $D={ }_{\mathrm{I}}$ for years $\mathrm{I} 766-74$ and zero otherwise. $z_{\mathrm{t}}=$ regression error term. Dickey-Fuller critical values are used for the (t-I) independent variables in panels A, B and C; see Enders (I995, p. 4I9). For panel A, Durbin's Alternative Tests for autocorrelation failed to reject the hypothesis of no serial correlation above the o.I level. For the regression in panels B, C and D, serial correlation was corrected by including one lag of the dependent variable. These corrected regressions were tested with Durbin's Alternative Test for autocorrelation which failed to reject the hypothesis of no serial correlation above the o.I level. OLS provides unbiased and consistently estimated coefficients, but biased-low standard errors when serial correlation is present. Adding lagged values of the dependent variable eliminates serial correlation for better assessment of standard error-statistical significance, but biases the coefficients on the other independent regressors (Maddala I977, pp. I47, 28 I-3; Pindyck and Rubinfeld I998, pp. I 59, 235). Thus, for panel C the OLS regression is used for coefficient accuracy and the regression corrected for serial correlation is used to assess statistical significance. The half-life to shocks are calculated using the following equation: $\left[-\ln (2) / \ln \left(\mathrm{I}+\mathrm{a}_{\mathrm{I}}\right)\right]$, where $\mathrm{a}_{\mathrm{I}}$ is the coefficient on the $(\mathrm{t}-\mathrm{I})$ independent variable in panels A, B and C. See Mark (200I, p. 32).

$\star \star \star$ Statistically significant above the o.or level.

$\star \star$ Statistically significant above the 0.05 level.

* Statistically significant above the o.I level.

Source: Figure I. See text for variable definitions and construction. 
This result is important for assessing the impact of the I764 Currency Act that removed legal tender status from new issues of colonial paper money. The Parliamentary removal of legal tender status of colonial paper monies did not reduce the TP Virginians placed on their own treasury notes. Legal tender status apparently was not necessary for the notes to be the preferred medium of exchange in local transactions. Moving the structural break one year back or one year forward from I766 reduces the regression fit, i.e. I766 is a local maximum. The I764 Currency Act was a non-issue regarding the value of Virginia's notes (Grubb 20I6a). It was more a political than an economic issue (Brock I975, pp. 465-527; Ernst 1973).

The most interesting result in Table 3 panel D is the positive and statistically significant effect of the amount of paper money per capita on $(T P-R D)$. Placing more paper money in circulation regardless of which treasurer was in charge increased the strain on executing redemptions as promised. As such, $R D$ should not fall, and so increases in TP must account for this positive association. More paper money in circulation per capita increased its ubiquity and familiarity of usage, which in turn led the public increasingly to treat this money as fiat-like currency. This process was accomplished by the public not time-discounting these notes when used in trade as much as would be required if they were just non-money zero-coupon barter bonds. As more notes were put into circulation, they increasingly displaced other means for making domestic transactions, such as barter, book credit, tobacco claims and specie coins.

Because the transaction premium was positively associated with the quantity of paper money in circulation, it absorbed the pressure to reduce the value of the paper money that sprang from increases in the quantity of paper money. Within the limits of an under-monetized economy, increases in the quantity of paper money increased its 'moneyness' value by increasing its usefulness as an internal medium of exchange within that economy. This explains why the classical quantity theory of money performs poorly when used to assess the value and performance of colonial paper monies (Grubb forthcoming).

\section{I}

Barter is when real goods or real assets directly, or ultimately, pay for real goods or real assets without using an intervening and easily transferable store-of-value instrument that is itself not a real good or real asset. Real assets include claims to specific future real goods or real value obligations. Money's definition must be separate from, or independent of, the non-money real goods or real asset value of the object identified as money. If it is not, then everything and anything traded is money, and we have a useless and meaningless definition of money. The model of money employed here achieves that separation and measures the 'moneyness' value versus real value portions of objects identified as money. 
Virginia's paper money was mostly a barter asset. It functioned as a zero-coupon bond and not a fiat currency. It traded below face value due to time-discounting, not depreciation. Scholars have habitually confused time-discounting for depreciation. It had a small transaction premium, i.e. a small 'moneyness' value, enough to make it the preferred medium of exchange for domestic transactions. This transaction premium was positively related to the quantity of paper money in circulation. As the quantity increased, it gained ubiquity and familiarity of use, leading citizens to pay a premium above its real-asset present value. In effect, citizens reduced the time-discounting they applied to the notes, thereby beginning a transition from barter asset toward having fiat currency characteristics. This identifies one mechanism by which real asset claims can transition into fiat currency. This association, given the under-monetized economy, siphoned off price inflation pressures coming from increases in the paper money supply, leaving little association between the quantity of paper money and prices (Grubb forthcoming). The small transaction premium is also consistent with the minor output gains associated with increases in paper money supplies found in some colonies (Rousseau 2007; Rousseau and Stroup 20I I). In years with monetary troubles, i.e. asset redemption worries, the paper money did experience a moderate risk discount. Counterfeiting, however, was not a major worry, at least for Virginia. The Virginia legislature had the tools and used them effectively to mitigate the effects of counterfeiting on the value of its paper money.

On these general patterns of assessment and performance, colonial Virginia's paper money was similar to that recently found for the paper money regimes of colonial New Jersey, colonial North Carolina and post-I764 colonial Maryland (Celia and Grubb 20I6; Cutsail and Grubb 20I7; Grubb 20I6b). What differs across colonies are the magnitudes and timing of these performance outcomes, the particular causes underlying the public finance dynamics controlling their systems, as well as the type and timing of shocks hitting their paper money systems. The history part of financial history matters. Virginia's actual financial history, namely the magnitudes of the effects, the dynamic path of values and the legislative reactive controls, was unique, as it was for other colonies. The model used here allows identifying, tracking and analyzing that uniqueness and its causes.

Submitted: 29 October 2017

Revised version submitted: I7 June 2018

Accepted: I 5 July 2018

First published online: 22 August 2018

\section{References}

BREEN, T. H. (1985). Tobacco Culture: The Mentality of the Great Tidewater Planters on the Eve of the Revolution. Princeton, NJ: Princeton University Press.

BROCK, L. V. (1975). The Currency of the American Colonies, 1700-1764. New York: Arno Press (first published I94I).

CARTER, S. B. et al. (eds). (2006). Historical Statistics of the United States Earliest Times to the Present, millennial edn, vol. 5. New York: Cambridge University Press. 
CELIA, J. and GRUBB, F. (20I6). Non-legal tender paper money: the structure and performance of Maryland's bills of credit, I767-75. Economic History Review, 69, pp. I I 32-56.

CUTSAIL, C. and GRUBB, F. (20I7). The paper money of colonial North Carolina, I7I 2-I774. NBER Working Paper no. 23783. www.nber.org/papers/w23783.

ENDERS, W. (I995). Applied Econometric Time Series. New York: John Wiley.

ERNST, J. A. (I973). Money and Politics in America, 1755-1775. Chapel Hill, NC: University of North Carolina Press.

GREENE, J. P. and JELLISON, R. M. (I96I). The Currency Act of I 764 in imperial-colonial relations, I764-I776. William and Mary Quarterly, I8, pp. 485-5I8.

GRUBB, F. (2004). The circulating medium of exchange in colonial Pennsylvania, I729-I775: new estimates of monetary composition, performance, and economic growth. Explorations in Economic History, 4I, pp. 329-6o.

GRUBB, F. (2006). Theory, evidence, and belief - the colonial money puzzle revisited: a reply to Michener and Wright. Econ Journal Watch, 3, pp. 45-72.

GRUBB, F. (20I I). German Immigration and Servitude in America, 1709-1920. New York: Routledge.

GRUBB, F. (2OI2). Chronic specie scarcity and efficient barter: the problem of maintaining an outside money supply in British colonial America. NBER Working Paper no. I 8099. www.nber.org/papers/wi8099.

GRUBB, F. (20I6a). Is paper money just paper money? Experimentation and variation in the paper monies issued by the American colonies from I690 to I775. Research in Economic History, 32, pp. I $47-224$.

GRUBB, F. (2016b). Colonial New Jersey paper money, I709-I775: value decomposition and performance. Journal of Economic History, 76, pp. I2 I6-32.

GRUBB, F. (20I7). Colonial Virginia's paper money regime, I755-I774: a forensic accounting reconstruction of the data. Historical Methods, 50, pp. 96-I I2.

GRUBB, F. (forthcoming). Colonial American paper money and the quantity theory of money: an extension. Social Science History, 43.

HAMMOND, B. (I99I). Banks and Politics in America. Princeton, NJ: Princeton University Press (first published I957).

HENING, W. W. (ed). (I969). The Statutes at Large; Being a Collection of All the Laws of Virginia from the First Session of the Legislature, in the Year 1619, vols. 6-9. Charlottesville, VA: University Press of Virginia (first published I8I9-2 I, Franklin Press, Richmond, VA).

HUTCHINSON, W.T. and RACHAL, W. M. E. (eds.). (I962). The Papers of James Madison, vol. I. Chicago: University of Chicago Press.

Journal of the Commissioners for Trade and Plantations: Preserved in the Public Records Office, January I759December I763 (I970). Nendeln, Liechtenstein: Kraus-Thomson (first published I935, Her Britannic Majesty's Stationery Office, London).

KENNEDY, J. P. (ed.) (I905). Journals of the House of Burgesses of Virginia, 1773-1776. Richmond, VA: Virginia State Library.

KENNEDY, J. P. (ed.) (I906a). Journals of the House of Burgesses of Virginia, 1766-1769. Richmond, VA: The Colonial Press, Everett Waddey Company.

KENNEDY, J. P. (ed.) (I906b). Journals of the House of Burgesses of Virginia, 1770-1772. Richmond, VA: The Colonial Press, Everett Waddey Company.

KENNEDY, J. P. (ed.) (I907). Journals of the House of Burgesses of Virginia, 1761-1765. Richmond, VA: The Colonial Press, Everett Waddey Company.

LABAREE, L. W. (ed.) (I959-70). The Papers of Benjamin Franklin, vols. I-I4. New Haven, CT: Yale University Press.

LEE, R. H. (I 825). The Memoir of the Life of Richard Henry Lee and His Correspondence, vol. I. Philadelphia: H. C. Carey and I. Lee.

MADDALA, G. S. (I977). Econometrics. New York: McGraw-Hill.

MARK, N. C. (200I). International Macroeconomics and Finance: Theory and Econometric Methods. Malden, MA: Blackwell.

MAYS, D. J. (1952). Edmund Pendleton, 1721-1803: A Biography, vol. I. Cambridge, MA: Harvard University Press.

MCCALlUM, B. T. (I992). Money and prices in colonial America: a new test of competing theories. Journal of Political Economy, Ioo, pp. I43-6I. 
MCCUSKER, J. J. (I978). Money and Exchange in Europe and America, 1600-1775. Chapel Hill, NC: University of North Carolina Press.

MCILWAINE, H. R. (ed.). (I908). Journals of the House of Burgesses of Virginia, 1758-1761. Richmond, VA: The Colonial Press, Everett Waddey Company.

MCILWAINE, H. R. (ed.). (I909). Journals of the House of Burgesses of Virginia, 1752-1755, 1756-1758. Richmond, VA: The Colonial Press, Everett Waddey Company.

MICHENER, R. (I987). Fixed exchange rates and the quantity theory in colonial America. CarnegieRochester Conference Series on Public Policy, 27, pp. 233-308.

MICHENER, R. (I988). Backing theories and currencies of eighteenth-century America: a comment. Journal of Economic History, 48, pp. 682-92.

MICHENER, R. W. (2015). Redemption theories and the value of American colonial paper money. Financial History Review, 22, pp. 3 I 5-35.

NEWMAN, E. P. (2008). The Early Paper Money of America, sth edn. Iola, WI: Krause Publications.

PINDYCK, R. S. and RUBINFELD, D. L. (I998). Econometric Models and Economic Forecasts, 4 th edn. New York: McGraw-Hill.

RICORD, F. W. (I982). Documents Relating to the Colonial History of the State of New Jersey, vol. I7. Trenton, NJ: John L. Murphy.

ROUSSEAU, P. L. (2007). Backing, the quantity theory, and the transition to the US dollar, I723-I 850. American Economic Review, 97, pp. 266-70.

ROUSSEAU, P. L. and STROUP, C. (201 I). Monetization and growth in colonial New England, I703-I 850. Explorations in Economic History, 48, pp. 600-I3.

SCOTT, K. (1957). Counterfeiting in Colonial America. Philadelphia: University of Pennsylvania Press.

SMITH, A. (I937). The Wealth of Nations. New York: Modern Library (first published I776).

SMITH, B. (I985a). American colonial monetary regimes: the failure of the quantity theory and some evidence in favor of an alternative view. Canadian Journal of Economics, I8, pp. 53 I-65.

SMITH, B. (I985b). Some colonial evidence on two theories of money: Maryland and the Carolinas. Journal of Political Economy, 93, pp. I I 78-2 I I.

SMITH, B. (I988). The relationship between money and prices: some historical evidence reconsidered. Quarterly Review, Federal Reserve Bank of Minneapolis, I2, pp. I8-3.

SUMNER, S. (I993). Colonial currency and the quantity theory of money: a critique of Smith's interpretation. Journal of Economic History, 53, pp. I39-45.

TILLSON, A. H. Jr (20I0). Accommodating Revolutions: Virginia's Northern Neck in an Era of Transformations, 1760-1810. Charlottesville, VA: University of Virginia Press.

WEST, R. C. (I978). Money in the colonial American economy. Economic Inquiry, I6, pp. I-I 5.

WICKER, E. (I985). Colonial monetary standards contrasted: evidence from the Seven Years' War. Journal of Economic History, 45, pp. 869-84.

William and Mary College Quarterly Historical Magazine (I9I2). 20, pp. 227-62. 